\title{
The Effects of Metacognition in Reading Comprehension Competence Based on Ruddell's Taxonomy
}

\author{
Siti Nurbaya ${ }^{1}$, Fathur Rokhman $^{2}$, Rustono $^{3}$, Subiyantoro $^{4}$ \\ \{siti_nurbaya@uny.ac.id ${ }^{1}$ \} \\ Universitas Negeri Semarang ${ }^{1,2,3,4}$
}

\begin{abstract}
This study examines the effects of metacognition on reading comprehension competence based on Ruddell's taxonomy and identifies competences of the taxonomy which have not been mastered by the students of the Department of Indonesian Literature and Language Education. This study used qualitative correlation to examine the effects of metacognition on reading comprehension competence and quantitative descriptive method to identify competences which have not been mastered by the students. Multiple choice question test was used to obtain the data of reading comprehension competence, and metacognition data was taken through closed-endLikert Scale. The results suggest metacognition does not have any effect on reading comprehension competence. The competences which have not been mastered by the students are: understanding supporting ideas, predicting competence, problem-solving competence, understanding cause and effect relation and information order. The results can be used as a reference for developing a learning design to improve reading comprehension competence.
\end{abstract}

Keywords: metacognition, Ruddell's taxonomy, reading comprehension competence

\section{Introduction}

Reading is an indispensable and essential activity in the whole process of human education. Reading allows people to get scientific knowledge. Consequently, there is no reason for people not to develop their reading competence. The statement supports UNESCO policy through Education for All (EFA) that provides rooms for the spread of literacy as the focus of education development "....the expansion of early childhood care and education, the universal primary education, the development of learning opportunities for youth and adults, the spread of literacy, the achievement of gender parity and gender equality in education, and improvements in education quality" (UNESCO, 2007) ${ }^{1}$.

The spread of literacy here means that education is developed with the spirit to improve the competence of reading, writing and counting. UNESCO must have strong argumentations to put forward the need to master the three competences. People need them to observe, understand and

\footnotetext{
${ }^{1}$ UNESCO. Literacy initiative for empowerment 2006-2015.vision and strategy paper (3rd.edition). UNESCO Institute for Lifelong Learning. (2007)

UNESCO. Education for all by 2015: Will we make it? EFA global monitoring Report 2008. UK: Oxford University Press. (2007)
} 
analyze life phenomenon so they can open up their horizon and knowledge about their potential and the environment around them used to improve their life quality.

Reading competence in this study refers to reading comprehension competence. A good competence of reading comprehension is considered as the capital of a nation (Harras, 1998) ${ }^{2}$. It also plays a central role in education as Farr (1984) ${ }^{3}$ argues that reading is the heart of education. It is not inherited; it needs to be developed and influenced by various factors. There are a number of factors that influence one's reading competence. In general, the competence is influenced by two major factors, internal and external factors. The former comes from family, economy and learning culture factors while the latter comes from motivation, interest, student personality, language competence combination and cognitive style (Zuchdi, 2004) ${ }^{4}$. The cognitive style here means thinking about what Livingstone $(1997)^{5}$ call metacognition.

According to Flavell $(1976)^{6}$, metacognition refers to one's knowledge concerning his/her cognitive processes, or anything related to them, e.g. learning-relevant properties of information or data. Similarly, Nelson $(1992)^{7}$ suggests that metacognition relies on a more complex process of thinking. He argues that metacognition is a process of thinking taking place at two levels which are closely related, meta-level and object-level. It is used by readers as a strategy when reading takes place.

However, metacognitive strategy is not individually stated despite the fact that it comes into action during the teaching and learning processes in the form of mental activity through a question strategy which does not just ask what question, but also aims to reflect, analyze and do critical thinking. The mastery of a good level of reading competence by university students in particular can be measured using various reading taxonomies.

Table 1. Ruddell's Reading Taxonomy

\begin{tabular}{llccc}
\hline \multicolumn{1}{c}{ Competence } & Factual & \multicolumn{2}{c}{ Level of Comprehension } \\
Interpretative & Applicative \\
\hline 1. Supporting ideas & & $\sqrt{ }$ & $\sqrt{ }$ \\
a. Identifying & $\sqrt{ }$ & $\sqrt{ }$ & $\sqrt{ }$ \\
b. Comparing & & $\sqrt{ }$ & $\sqrt{ }$ \\
c. Classifying & & $\sqrt{ }$ & $\sqrt{ }$ \\
2. Order & $\sqrt{ }$ & $\sqrt{ }$ & $\sqrt{ }$ \\
3. Cause and effect & $\sqrt{ }$ & $\sqrt{ }$ & $\sqrt{ }$ \\
4. Main Ideas & & $\sqrt{ }$ & $\sqrt{ }$ \\
5. Predicting & $\sqrt{ }$ & $\sqrt{ }$ & $\sqrt{ }$ \\
6. Assessing & & & \\
a. Self-Assessment & & & \\
b. Character Identification & & & \\
c. Author's motive identification & & & \\
7. Problem solving & & & \\
\hline
\end{tabular}

${ }^{2}$ Harras, Kholid A. \& Lilis, Sulistianingsih. Membaca I. Jakarta: Universitas Terbuka. (1997)

${ }^{3}$ Farr, R. What can be measured?. Cinemark, Del. International Reading Association. (1984)

${ }^{4}$ Zuchdi, Darmiyati. Peningkatan Kemampuan Memahami Bacaan dan Kemandirian dengan Teknik Rencana Prabaca Litera. Jurnal Penelitian Bahasa Sastra danPengajarannya. Volume 3 (2), July. (2008)

${ }^{5}$ Livingson, Jeniver A. Metacognition: an overview. (1997)

${ }^{6}$ Flavell,H. Jonh. Metacognitive and cognitive monitoring: a new area of cognitive-development inquiry in metacognition core reading. 1992. Allyn Bacon. London. (1997)

${ }^{7}$ Nelson, O.Thomas. Metacognition core reading. Allyn and Bacon. Boston. (1992) 
Table 1, one of the taxonomies that can be used is the one developed by Ruddell. His taxonomy is the result of revision to the taxonomy by Barret "the Taxonomy of the Cognitive and Affective of Reading Comprehension" (Harris and Myers, 2004) ${ }^{8}$. Initially, Barret's taxonomy consisted of five competences that Ruddell simplified, but it covers the five taxonomies by Barret. Reading competence based on Ruddell's taxonomy is a required reading competence with seven phases, each with three sub-competencies.

\section{Research Methodology}

This study used a quantitative method. The data was analyzed using parametric statistic with statistical testing using product moment correlation and descriptive qualitative method. The samples consisted of 70 students from the Department of Indonesian Literature and Language Education of Universitas Negeri Yogyakarta. They were selected through random sampling from 180 students taking reading comprehension course in the $4^{\text {th }}$ semester. The instruments of this study consisted of 1) a reading comprehension test developed by using Ruddell's taxonomy with 40 multiple choice questions with four answer options and 2) a questionnaire using a closed-endLikert Scale with four answer options. The instrument validity was conducted using Item Response Theory in the form of Quest Program.

According to the result of MEAN INFIT MNSQ 1.00 and SD 0.16, overall the instrument items were in accordance with Ras model. The value of reliability test was 0.86 . This indicated that the instruments were reliable in accordance with the instrument criteria. Theme cognition data were obtained through 40 Closed-end Likert Scale questionnaires, and their reliability were achieved using Croncbah Alfa. Based on the analysis of the results, the reliability coefficient was 0.807 (very high), so it was considered reliable to be used to collect the data for this research.

\section{Results and Discussion}

The focuses of this study are: 1) does metacognition based on Ruddell's taxonomy have effects on the reading comprehension competence of the students? 2) which competences are still not mastered by the students according to the Ruddell's taxonomy?

Based on the focuses above, the results suggest that

1) Metacognition does not have any effect on the reading comprehension competence of the students. This is found through correlational Product Moment analysis. The calculation reveals that $r$ value is 0.844 with the significance 0.362 , which means that 0.362 is bigger than 0.05 that indicates that metacognition based on Ruddell's taxonomy does not have any effect on the reading comprehension of the students.

2) Reading competences based on Ruddell's taxonomy that have not been mastered or answered correctly are: a) understanding the supporting ideas $(94.2 \%)$, or only $5.8 \%$ of the students who are able to answer correctly, b) predicting competence $(85.7 \%)$, or only $14.3 \%$ of the students who are able to answer correctly c) problem solving competence

\footnotetext{
8 Harris,B.L, and Myers.S. Samuel. Teacher'guide manual for formulating reading comprehension question. The New Horison for Primary School (NHP) is a Seven-Year, Join Initiation of Government of Jamaica (GOJ) and the United States Agency for International Development (USAID).
} 
$(68.7 \%)$ or only $31.3 \%$ of the students who are able to do it, while understanding cause and effect $(65,7 \%)$ or only $34.3 \%$ of the students who are able to answer correctly. The same result is also found in the competence of understanding the order of information with $65.7 \%$ with wrong answers or only $34.3 \%$ of the students who are able to answer correctly.

The results of this study contradict the results of the previous studies on the effects of metacognition on reading competence. The following are studies that support the effects of metacognition on reading competence. Al-Tamimi $(2006)^{9}$ examined the metacognition strategy through samples of 60 junior high students in Yemen. He reveals that metacognition is important to improve the reading comprehension of a text. He also argues that teachers have also found the benefits of using metacognition strategy in English reading comprehension classes.

Another proponent of the metacognition strategy was the study by Iwai $(2011)^{10}$ entitled "The Effects of Metacognitive Reading Strategies: Pedagogical Implementation for EFL/ESL Teacher". Her study reveals that the use of metacognition strategy is found to help the students become independent in learning. To the same extent, Thohari $(2000)^{11}$ examined the effects of metacognition on the improvement of problem-solving competence. He concludes that metacognition strategy results in the way of controlling the process of thinking in which critical thinking competence is developed.

Despite the fact that the aforementioned studies confirm the results of the previous studies on metacognition strategy, using Ruddell's taxonomy this study has found no indication to draw such conclusion. The absence of metacognition effect on the reading competence is, to some extent, driven by the fact that the students under study have not used the strategy, goal and regulation of metacognition that they have to:1) identify the supporting ideas in a text, 2) predict facts , to interpret and make meanings of the application of the understanding of main ideas in a text, 3) to solve problems, and to identify the order of information in a text.

The results also suggest that low level of reading competence of the students under study indicates that the metacognition that draws on cognition about cognitive phenomena as proposed by Nelson (1992) $)^{12}$ and takes place at meta-level and object level. It has not been used properly by the students when doing the test developed using Ruddell's taxonomy. This suggests that the effects of metacognition are dynamic in nature. The aspects of metacognition such as strategy, goal and regulation have not been used to answer the questions in the test. In other words, in some studies metacognition is found to have effects on the improvement of reading competence. In this study, based on Ruddell's taxonomy, such fact is not found. Three aspects of metacognition are considered to complement each other to help students understand a text properly so that this will result in a competence that will be used to comprehend a text being read. Therefore, making metacognition as a competence demands that it should be practiced systematically and continuously.

In addition to the aforementioned factors, the following factors that operate in combination and are found to be important during the process of reading are 1) knowledge about the text and its vocabulary, 2) thinking competence, 3 ) preliminary knowledge about the content of the text

\footnotetext{
${ }^{9}$ Omer Nasser, Al-Tamimi Mubarak. The effect of direct reading strategy instruction on students' reading comprehension, metacognitive strategy awareness, and reading attitudes among eleventh grade students. Thesis. Universiti Sains Malaysia. (2006)

${ }^{10}$ Iwai. The effects of metacognitive reading strategies: Pedagogical Implementation for EFL/ESL Theacher. (2011)

11 Thohari, Khamrin. Peningkatan kemampuan problem solving melalui peningkatan kemampuan metakognisi. (2000)

${ }^{12}$ Nelson, O.Thomas. Metacognition core reading. Allyn and Bacon. Boston. (1992)
} 
before reading or schemata and 4) attitude before and after reading activity about the content of the text (Ruddell, 2005) ${ }^{13}$.

Sadoski (2004) suggests that the teaching of reading should be well-designed. Design, instruction and learning materials which are clear, purposeful, and measurable are important aspects that influence the development of reading competence in the students. Teachers are required to be familiar with the learning concepts of reading and to design them to be meaningful learning materials for their students (Sadoski,2004) ${ }^{14}$. Thus, reading competence, if ordered in line, can be classified as novice, proficient and complex competence. Novice competence begins with the ability to decode words up to understanding the meaning of a sentence. Proficient competence is enlarged from the novice competence leading to interpreting competence beyond meanings that is contained in a text or meanings intended by the author. Complex competence includes seven competences proposed by Ruddell and some of which are divided into sub competences (see the table on Ruddell's taxonomy).

Based on the discussion above, it can be justified that although the students have good schemata, the reading competence is found not to be influenced by the metacognition based on Ruddell's taxonomy. The reading competences based on Ruddell's taxonomy that have not been mastered or answered correctly consist of 1) understanding the supporting ideas $(94.2 \%)$, or only $5.8 \%$ of the students who are able to answer correctly, 2) predicting competence $(85.7 \%)$, or only $14.3 \%$ of the students who are able to answer correctly 3 ) problem-solving competence $(68.7 \%)$ or only $31.3 \%$ of the students who are able to do it while understanding cause and effect $(65.7 \%)$ or only $34.3 \%$ of the students who are able to answer correctly. The same result is also found in the competence of understanding the order of information with $65.7 \%$ with wrong answers or only $34,3 \%$ of the students who are able to answer correctly.

\section{Conclusions}

Based on the findings, analysis results and discussions, this study concludes that although metacognition is theoritically assumed to have effects on reading competence, this study has found that it is not so based on the Ruddell's Taxonomy. In addition, reading competences that students find hard to master based on Ruddell's taxonomy are the competences of interpreting, understanding supporting ideas, predicting, and problem solving. To improve the reading competence based on Ruddell's taxonomy, it is suggested that further elaboration is required about the learning model and or learning materials that help students learn and understand the competences included in Ruddell's taxonomy.

\footnotetext{
${ }^{13}$ Ruddell, R. Martha. Teaching content reading and writing. Fourth Edition. USA: Hermitage Publishing Services. (2005)

${ }^{14}$ Sadoski, Mark. Conceptual foundation of teaching reading. The Guilford Press A Division of Guilford Publications, Inc. New York. (2004)
} 


\section{References}

[1] Farr, R. What can be measured?. Cinemark, Del. International Reading Association. (1984)

[2] Flavell,H. Jonh. Metacognitive and cognitive monitoring: a new area of cognitive-development inquiry in metacognition core reading. 1992. Allyn Bacon. London. (1997)

[3] Harris,B.L, and Myers.S. Samuel. Teacher'guide manual for formulating reading comprehension question. The New Horison for Primary School (NHP) is a Seven-Year, Join Initiation of Government of Jamaica (GOJ) and the United States Agency for International Development (USAID).

[4] Harras, Kholid A. \& Lilis, Sulistianingsih. Membaca I. Jakarta: Universitas Terbuka. (1997)

[5] Harris, A.J. \& Sipay, E.R. How to increase reading ability. New York: Longman. (1980)

[6] Hergenhahn, B.R and Olson Matthew H. Theory of learning. Kencana Prenada Media Group. Jakarta. (2002)

[7] Iwai. The effects of metacognitive reading strategies: Pedagogical Implementation for EFL/ESL Theacher. (2011)

[8] Livingson, Jeniver A. Metacognition: an overview. (1997)

[9] John, Bourmont. An operational definition of comprehension instruction in K S. Godman T.J Fleming (Edt). Psycholinguistics and Teaching Reading. Nweark, Del: International of Reading Association. (1969)

[10] Nelson, O.Thomas. Metacognition core reading. Allyn and Bacon. Boston. (1992)

[11] Omer Nasser, Al-Tamimi Mubarak. The effect of direct reading strategy instruction on students' reading comprehension, metacognitive strategy awareness, and reading attitudes among eleventh grade students. Thesis. Universiti Sains Malaysia. (2006)

[12] Ruddell, Robert B. Developing comprehension abilities: implication from research for an instructional Framework. (1978)

[13] Ruddell, R. Martha. Teaching content reading and writing. Fourth Edition. USA: Hermitage Publishing Services. (2005)

[14] Sadoski, Mark. Conceptual foundation of teaching reading. The Guilford Press A Division of Guilford Publications, Inc. New York. (2004)

[15] Thohari, Khamrin. Peningkatan kemampuan problem solving melalui peningkatan kemampuan metakognisi. (2000)

[16] UNESCO. Education for all by 2015: Will we make it? EFA global monitoring Report 2008. UK: Oxford University Press. (2007)

[17] UNESCO. Literacy initiative for empowerment 2006-2015.vision and strategy paper (3rd.edition). UNESCO Institute for Lifelong Learning. (2007)

[18] Zuchdi, Darmiyati. Strategi meningkatkan kemampuan membaca: peningkatan komprehensi. Yogyakarta: UNY Press. (2005)

[19] Zuchdi, Darmiyati. Peningkatan Kemampuan Memahami Bacaan dan Kemandirian dengan Teknik Rencana Prabaca Litera. Jurnal Penelitian Bahasa Sastra danPengajarannya. Volume 3 (2), July. (2008) 